\title{
The Influence of Organizational Culture and Organizational Climate Mediated by Motivation on Employee Performance in PT Talenta Wirama Berkat
}

\author{
Johana Maria Angela Prima Vidia ${ }^{1}$, Hery Winoto Tj. ${ }^{*}$, Lambok D. R. Tampubolon ${ }^{1}$, \\ Saparso Saparso ${ }^{1}$
}

\author{
${ }^{1}$ Faculty of Economics and Business, Krida Wacana Christian University, Jakarta 11470, Indonesia \\ *Corresponding author. Email: hery.winoto@ukrida.ac.id
}

\begin{abstract}
This research discusses about organizational culture, organizational climate and motivation on employee performance in an event management company. The purpose of this research was to examine the influence of organizational culture and organizational climate through motivation on employee performance. This research population consists of 50 employees of PT Talenta Wirama Berkat. The research data was obtained through questionnaires and research analysis techniques used Structural Equation Modeling (SEM) with the SmartPLS 3.0 program. This research shows that employee performance will be better and improved due to the organizational culture and organizational climate set by the company and the motivation provided by the company. Therefore, companies must pay attention to organizational culture, organizational climate, and motivation which is suitable with the field of business and the development of current era or work-related industry so that employee performance can be higher and better for the company's development and progress. Keywords: Organizational Culture, Organizational Climate, Motivation and Employee Performance
\end{abstract}

\section{INTRODUCTION}

Sobirin [1] argued that an organization is a social system that has a regular work pattern established by human beings and has a group of people in order to support the achievement of a certain set of goals. Organizations can also be defined as social units established by human beings for a long period of time, consisting of a group or several people, at least two, who have structured and organized activities, designed to achieve certain goals, and have an identity to differentiate them from others. In a corporate organization, employee performance is one variable that can be used to measure the organizational performance, so it is important to periodically evaluate work performance to maintain the consistency and improve organizational performance. Employee performance is a very important element for the company, because the company can succeed in achieving its goals, which is greatly influenced by maximum or optimal employee performance.

PT Talenta Wirama Berkat is a company engaged in event management. The researcher chose PT Talenta Wirama Berkat as the place where the research was conducted, because PT Talenta Wirama Berkat is one of the event management companies used by one of the leading fast moving consumer goods companies in Indonesia which requires PT Talenta Wirama Berkat to have good competence.

Researchers identified that there was a problem that occurred at PT Talenta Wirama Berkat, namely that employee performance had decreased, marked by no increase in employee Key Performance Indicators (KPI) for the last four years from 2016 to 2019. Employee's KPI are processed more briefly through the following table:

Table 1 2016-2019 Employee's KPI

\begin{tabular}{cccc}
\hline No. & Year & Target & Actual \\
\hline 1 & 2016 & $100 \%$ & $75 \%$ \\
\hline 2 & 2017 & $100 \%$ & $75 \%$ \\
\hline 3 & 2018 & $100 \%$ & $75 \%$ \\
\hline 4 & 2019 & $100 \%$ & $75 \%$ \\
\hline Source:
\end{tabular}

Source: PT Talenta Wirama Berkat

The employee's KPI for the past four years have fallen short of company expectations, because the percentage of employee's KPI achievements has not increased. The company hopes that employee's KPI can reach at least $90 \%$ of the target. With the phenomenon of sub-optimal employee performance due to the factors of organizational culture, organizational climate, and motivation, that affect employee performance, the authors were eager to conduct this research. Thus, the title is determined "The Influence of Organizational Culture and Organizational Climate Mediated by Motivation on Employee Performance in PT Talenta Wirama Berkat". 


\section{THEORETICAL FRAMEWORK}

\subsection{Organizational Culture $\left(X_{1}\right)$}

Organizational culture is a system of shared meanings held by its members that differentiates the organization from others [3]. The indicators based on Schein [4] are:

a. External Adaptation: Mission and strategy, objectives, basic means, measurement of success, back-up strategy.

b. Internal integration: Common language, group boundaries, placement of status and or power, relationships in groups, rewards and rewards, explain what cannot be explained.

c. Basic assumptions: The nature of environment, the nature of human being activities, the nature of reality and truth, the nature of time, the nature of human truth, the nature of human being relations, homogeneity vs heterogeneity.

\subsection{Organizational Climate $\left(X_{2}\right)$}

Organizational climate is a description of how individuals feel the organizational culture [5]. The indicators based on Hardjana [6] are:

a. Structure

b. Responsibility

c. Warmth or Support

d. Reward

e. Conflict

f. Performance Standards or Expectations

g. Organizational Identity

h. Risk

\subsection{Motivation (Z)}

Motivation is a process which explains the intensity, direction, and persistence of efforts in achieving a goal [7]. The indicators based on Emil [7] are:

a. Physiological Needs

b. Security Needs

c. Social Needs

d. The Need for Self Esteem

e. Self-Actualization Needs

\subsection{Employee Performance $(Y)$}

Performance originates from job performance or actual performance (actual work performance or achievement by a person), namely the work-related quality and quantity achieved by employees in carrying out their duties according to the responsibilities assigned to them [8]. The indicators based on [9] are:
a. Quality
b. Quantity
c. Timeliness
d. Cost Effectiveness
e. Need for Supervisor
f. Interpersonal Impact

\subsection{Conceptual Framework}

The relationship between organizational culture $\left(\mathrm{X}_{1}\right)$, organizational climate $\left(\mathrm{X}_{2}\right)$ through motivation $(\mathrm{Z})$ on employee performance (Y) in this study is illustrated by a constellation of relationships among variables as displayed in Figure 1 below:

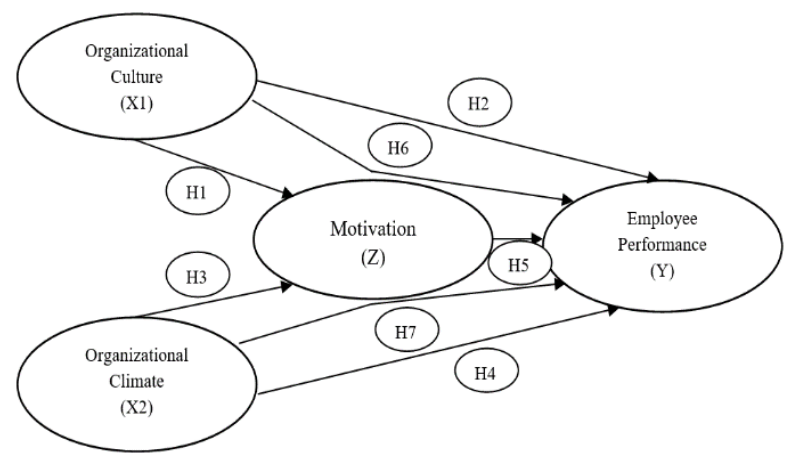

Figure 1 Conceptual Framework

Based on the conceptual framework above, the statistical hypotheses are formulated, namely; The relationship between organizational culture $\left(\mathrm{X}_{1}\right)$ and organizational climate $\left(\mathrm{X}_{2}\right)$ on employee performance $(\mathrm{Y})$ mediated by motivation $(\mathrm{Z})$. The hypothesis developments are described as follows:

$\mathrm{H}_{1}$ : Organizational culture $\left(\mathrm{X}_{1}\right)$ influences motivation $(\mathrm{Z})$.

$\mathrm{H}_{2}$ : Organizational culture $\left(\mathrm{X}_{1}\right)$ influences employee performance $(\mathrm{Y})$.

$\mathrm{H}_{3}$ : Organizational climate $\left(\mathrm{X}_{2}\right)$ influences motivation (Z).

$\mathrm{H}_{4}$ : Organizational climate $\left(\mathrm{X}_{2}\right)$ influences employee performance $(\mathrm{Y})$.

$\mathrm{H}_{5}$ : Motivation (Z) influences employee performance (Y).

$\mathrm{H}_{6}$ : Organizational culture $\left(\mathrm{X}_{1}\right)$ influences employee performance $(\mathrm{Y})$ mediated by motivation $(\mathrm{Z})$.

$\mathrm{H}_{7}$ : Organizational climate $\left(\mathrm{X}_{2}\right)$ influences employee performance $(\mathrm{Y})$ mediated by motivation $(\mathrm{Z})$.

\section{RESEARCH METHOD}

Researchers used the associative quantitative research in order to determine the relationship between more than two variables and its influences using a questionnaire.

Winarni [2] stated that the population is an interesting group, whereas this group is an object to generalize the research results. The population used in this research were all employees of PT Talenta Wirama Berkat with a total of 50 peoples. The sample is part of the population, thus the type of sample used must reflect the population. The sample technique of this research is a census or saturated sample, namely the research was conducted on the entire population, namely 50 (fifty) samples from the employees of PT Talenta Wirama Berkat. 


\section{ANALYSIS AND DISCUSSIONS}

\subsection{Outer Model}

Table 2 Construct Reliability and Validity

\begin{tabular}{|l|c|c|c|}
\hline \multicolumn{1}{|c|}{ Variables } & $\begin{array}{c}\text { Cronbach's } \\
\text { Alpha }\end{array}$ & $\begin{array}{c}\text { Composite } \\
\text { Reliability }\end{array}$ & AVE \\
\hline $\begin{array}{l}\text { Organizational } \\
\text { Culture }\left(\mathrm{X}_{1}\right)\end{array}$ & 0.898 & 0.922 & 0.665 \\
\hline $\begin{array}{l}\text { Organizational } \\
\text { Climate }\left(\mathrm{X}_{2}\right)\end{array}$ & 0.973 & 0.975 & 0.711 \\
\hline $\begin{array}{l}\text { Employee } \\
\text { Performance (Y) }\end{array}$ & 0.942 & 0.950 & 0.613 \\
\hline Motivation (Z) & 0.937 & 0.946 & 0.639 \\
\hline
\end{tabular}

Source: The Results of Data Processing with SmartPLS 3

Based on data analysis result, it can be seen that the variables of Organizational Culture $\left(\mathrm{X}_{1}\right)$, Organizational Climate $\left(\mathrm{X}_{2}\right)$, Motivation ( $\left.\mathrm{Z}\right)$, and Employee Performance (Y) have the AVE values higher than 0.5, Cronbach's Alpha higher than 0.7, and Composite Reliability higher than 0.7. Based on these results, all indicators in these variables are declared valid and reliable.

\subsection{Inner Model-Multiple Regression Test}

Table 3 Partial Least Square Boostraping - Path Coefficients Test Results

\begin{tabular}{|c|c|c|}
\hline & Coefficient & p-Values \\
\hline $\begin{array}{l}\text { Organizational Culture }\left(\mathrm{X}_{1}\right) \rightarrow \\
\text { Employee Performance }(\mathrm{Y})\end{array}$ & 0.333 & 0.017 \\
\hline $\begin{array}{l}\text { Organizational Culture }\left(\mathrm{X}_{1}\right) \rightarrow \\
\text { Motivation }(\mathrm{Z})\end{array}$ & 0.612 & 0.000 \\
\hline $\begin{array}{l}\text { Organizational Climate }\left(\mathrm{X}_{2}\right) \rightarrow \\
\text { Employee Performance }(\mathrm{Y})\end{array}$ & 0.229 & 0.037 \\
\hline $\begin{array}{l}\text { Organizational Climate }\left(\mathrm{X}_{2}\right) \rightarrow \\
\text { Motivation }(\mathrm{Z})\end{array}$ & 0.414 & 0.000 \\
\hline $\begin{array}{l}\text { Motivation }(\mathrm{Z}) \rightarrow \text { Employee } \\
\text { Performance }(\mathrm{Y})\end{array}$ & 0.406 & 0.016 \\
\hline
\end{tabular}

Source: The Results of Data Processing with SmartPLS 3

Based on the results in Table 3, the regression equation can be formulated as follow:

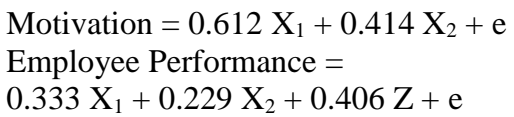

\section{3. $R$-Square \& $Q$-Square Test}

The analysis of coefficient of determination is done to calculate the contribution of variables $(\mathrm{X})$ and $(\mathrm{Z})$ to variable $(\mathrm{Y})$. A measure which is most commonly used to examine the structural model is $\mathrm{R}^{2}$. This $\mathrm{R}^{2}$ measures the predictive power of this model, which is calculated as the square of the correlation between the actual value and predicted value of the endogenous variable. The value of $\mathrm{R}^{2}$ ranges from 0 to 1 . Higher $R^{2}$ indicates higher prediction accuracy. Wahyoedi [10] suggested that the $\mathrm{R}^{2}$ value of $0.75,0.50$, or 0.25 , can be interpreted as substantial, moderate, or weak, for the latent endogenous variables. It can also be stated that the $\mathrm{R}^{2}$ of 0.67 is strong, 0.33 is moderate, and 0.19 is weak. Based on the $\mathrm{R}^{2}$ test, we provide the $\mathrm{R}^{2}$ for Motivation $(\mathrm{Z})$ as much as 0.870 , that indicates a substantial or strong level of prediction. This result illustrates that the motivation variable can be explained by organizational culture and organizational climate by $87 \%$, while the remaining $13 \%$ is explained by other variables out of the scope of this research. Meanwhile, the $\mathrm{R}^{2}$ value of the Employee Performance variable (Y) of 0.813 indicates a substantial or strong prediction. This means that the employee performance variable can be explained by organizational culture, organizational climate, and motivation as much as $81.3 \%$, hence the remaining $18.7 \%$ is explained by other variables out of this research.

Based on the Q-Square predictive relevance test, the $\mathrm{Q}^{2}$ value obtained is 0.9757 . That way, this research shows the diversity of the research as much as $97.57 \%$, thus the remaining $2.43 \%$ is explained by other variables which are not used in this research. With the results obtained, this research model has a good goodness-of-fit.

\subsection{Hypothesis Tests}

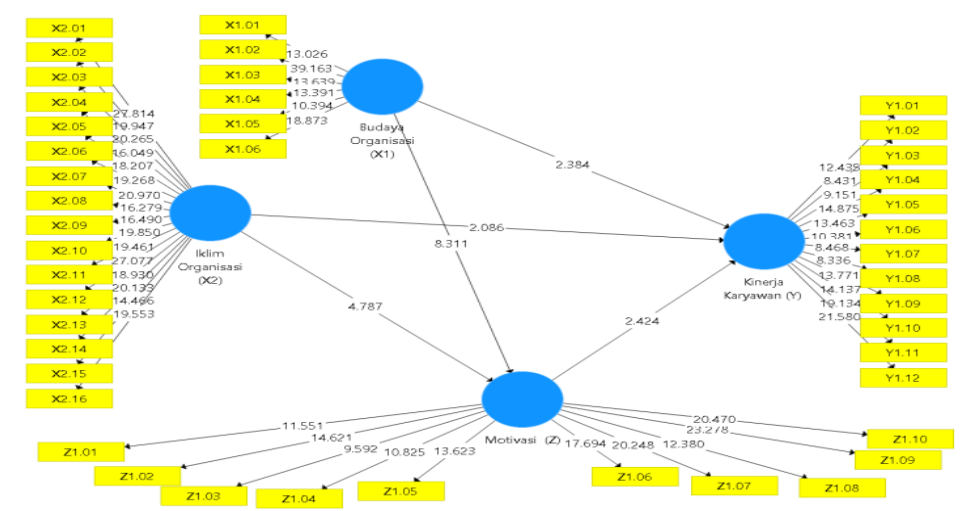

Figure 2 Path Model of Regression T-Value 
The results based on the hypothesis tests are described below:

1. The first hypothesis examines the influence of organizational culture on motivation among the employees of PT Talenta Wirama Berkat. The variable of organizational culture on motivation produces a sigvalue of 0.000 (less than 0.05 ). Thus, $\mathrm{H}_{1}$ was accepted. It can be concluded that the organizational culture variable significantly influences the motivation among the employees of PT Talenta Wirama Berkat.

2. The second hypothesis examines the influence of organizational culture on employee performance of PT Talenta Wirama Berkat. The variable of organizational culture on employee performance produces a sig-value of 0.017 (less than 0.05). Thus, $\mathrm{H}_{2}$ was accepted. It can be concluded that the organizational culture variable significantly influences the performance of employees of PT Talenta Wirama Berkat.

3. The third hypothesis examines the influence of organizational climate on the motivation among the employees of PT Talenta Wirama Berkat. The organizational climate variable on motivation produces a sig-value of 0.000 (less than 0.05 ). Thus, $\mathrm{H}_{3}$ was accepted. It can be concluded that the organizational climate variable significantly influences the motivation among the employees of PT Talenta Wirama Berkat.

4. The fourth hypothesis examines the influence of organizational climate on the performance of employees of PT Talenta Wirama Berkat. The variable of organizational climate on employee performance produces a sig-value of 0.037 (less than 0.05 ). Thus, $\mathrm{H}_{4}$ was accepted. It can be concluded that the organizational climate variable significantly influences the performance of employees of PT Talenta Wirama Berkat.

5. The fifth hypothesis examines the influence of motivation on the performance of employees of PT Talenta Wirama Berkat. The motivation variable on employee performance produces a sig-value of 0.016 (less than 0.05). Thus, $\mathrm{H}_{5}$ was accepted. It can be concluded that the motivation variable significantly influences the employee performance of PT Talenta Wirama Berkat.

Table 4 Partial Least Square Boostraping - Indirect Influence Test Results

\begin{tabular}{|l|c|c|}
\hline \multicolumn{1}{|c|}{ Indirect Influence } & Coefficient & p-Values \\
\hline Organizational Culture $\left(\mathrm{X}_{1}\right) \rightarrow$ & 0.248 & 0.024 \\
Employee Performance (Y) & & 0.035 \\
\hline Organizational Climate $\left(\mathrm{X}_{2}\right) \rightarrow$ & 0.168 & \\
Employee Performance (Y) & & \\
\hline
\end{tabular}

Source: The Results of Data Processing with SmartPLS 3

6. The sixth hypothesis examines the influence of organizational culture on performance through the motivation, among the employees of PT Talenta Wirama Berkat. The organizational culture variable has a significant influence on employee performance, the organizational culture variable has a significant influence on motivation, and the motivation variable has a significant influence on employee performance, with a sig-value of $0.024(<0.05)$. Thus, $\mathrm{H}_{6}$ was accepted. This means that the influence of organizational culture on employee performance is partially mediated by motivation.

7. The seventh hypothesis examines the influence of organizational climate on performance through the motivation, among the employees of PT Talenta Wirama Berkat. The organizational climate variable significantly affects employee performance, the organizational climate variable significantly affects motivation, and the motivation variable significantly affects employee performance. It can also be seen that the variable of organizational climate on employee performance produces a sig-value of $0.035(<0.05)$. Thus, $\mathrm{H}_{7}$ was accepted. This means that the influence of organizational climate on employee performance is partially mediated by motivation.

Based on the results, it can be concluded that all variables in this research influence the employee performance positively and also support the results of previous researches.

\section{CONCLUSIONS}

In this research, the conclusions can be made as follows:

1. The organizational culture is proven to have significant influence on motivation among the employees of PT Talenta Wirama Berkat. If the organizational culture increases, it will increase the employee motivation of PT Talenta Wirama Berkat.

2. The organizational culture is proven to have significant influence on employee performance of PT Talenta Wirama Berkat. If the organizational culture increases, it will increase the employee performance of PT Talenta Wirama Berkat.

3. The organizational climate is proven to have significant influence on motivation among the employees of PT Talenta Wirama Berkat. If the organizational climate increases, it will increase the employee motivation of PT Talenta Wirama Berkat.

4. The organizational climate is proven to have significant influence on employee performance of PT Talenta Wirama Berkat. If the organizational climate is improved, it will improve the employee performance of PT Talenta Wirama Berkat.

5. The motivation is proven to have significant influence on employee performance of PT Talenta Wirama 
Berkat. If the motivation increases, it will increase the employee performance of PT Talenta Wirama Berkat.

6. The motivation mediates the influence of organizational culture on employee performance of PT Talenta Wirama Berkat. If the organizational culture and motivation increase, it will further increase the employee performance of PT Talenta Wirama Berkat.

7. The motivation mediates the influence of organizational climate on employee performance of PT Talenta Wirama Berkat. If the organizational climate and motivation increase, it will further increase the employee performance of PT Talenta Wirama Berkat.

\section{REFERENCES}

[1] Sobirin, A., Organizational Culture, Definition,

Meaning and Application in Organizational Life, Third, Yogyakarta: UPP STIM YKPN, 2019.

[2] Winarni, E. W., Qualitative Quantitative Research; Classroom Action Research and Research

Development, Jakarta: Bumi Aksara, 2018.

[3] Aryana, P. and Tj., H. W., The Influence of Organizational Culture, Work Ethics and Loyalty on Employee Performance (Case research of non-academic employees of XYZ University), in: Scientific Business Management, 17 (2), pp. 89-110, 2017.

[4] Schein, Organizational Culture and Leadership 4th Edition, San Francisco: Jossey Bass, 2010.

[5] Rambe, P. A., The Influence of Job Characteristics, Organizational Climate and Job Satisfaction on Employee Performance, in: Journal of Dimensions, 7 (2), pp. 368-392, 2018.

[6] Hardjana, A., Organizational Communication; Leadership and Interaction Strategy, Second, Depok: PT RajaGrafindo Persada, 2019.

[7] Emil, M., The Influence of Leadership Style, Organizational Culture and Work Environment on Employee Performance through Motivation at PDAM Tirta Mayang Kota Jambi, in: J-MAS (Journal of Management and Science), 3 (1), pp. 26-38, 2018.

[8] Sudaryo, Y., Ariwibowo, A. \& Sofiati, N. A., Human Resource Management; Indirect Compensation and Physical Work Environment, Yogyakarta: ANDI Publisher, 2018.

[9] Yusniar, The Influence of Organizational Culture on Performance through Motivation at the Regional Secretariat of North Aceh Regency, in: Journal of Economic Management \& Business, 17 (1), 2016.
[10] Wahyoedi, S., Data Analysis in Smart-PLS and Warp-PLS Structural Equation Modeling, in: Business Management Scientific, pp. 1-20, 2020. 